\title{
Analysis of the long-term dynamics of external doses of the population after the Chernobyl accident
}

\begin{abstract}
Vladislav Yu. Golikov
Saint-Petersburg Research Institute of Radiation Hygiene after Professor P.V. Ramzaev, Federal Service for Surveillance on Consumer Rights Protection and Human Well-Being, Saint-Petersburg, Russia

The paper presents an analysis of the dynamics of individual doses of external exposure among the population living for almost 20 years in the territories affected by the radioactive contamination due to the Chernobyl NPP accident. The dynamics of the average effective dose of the external exposure of the inhabitants in the period of 5 to 20 years after the Chernobyl fallout is well described by processes that consider the radioactive decay of cesium radionuclides and their natural migration. The distribution of individual doses of external exposure among residents, normalized to the average dose in the settlement corresponds to a logarithmically normal law with the time-stable parameters: the geometric mean $\sim 0.9$ and geometric standard deviation $\sim 1.5$, which allows, in particular, predicting the dose for the critical group of population or for a representative person. Comparison of the mean effective doses of external exposure of the settlement residents estimated based on the results of two different measurement technologies (using $T L D$-method and measurements of dose rates in air in various settlement locations) indicated their good agreement for the 17 years period after the fallout. For two settlements, where measurements were performed in 2003, the relative differences in mean effective doses did not exceed $12 \%$. It allows using the previously developed model of external exposure for dose estimation to the population residing on the territories contaminated after the Chernobyl accident.

Key words: Chernobyl accident, external exposure of people, effective dose, gamma-radiation dose rate, thermoluminescent dosemeters.
\end{abstract}

\section{Анализ долгосрочной динамики доз внешнего облучения населения после Чернобыльской аварии}

\section{В.Ю. Голиков}

Санкт-Петербургский научно-исследовательский институт радиационной гигиены имени профессора П.В. Рамзаева, Федеральная служба по надзору в сфере защиты прав потребителей и благополучия человека, Санкт-Петербург, Россия

\begin{abstract}
В работе представлен анализ динамики индивидуальных доз внешнего облучения населения, проживающего в течение почти 20 лет на территориях, подвергшихся радиоактивному загрязнению в результате Чернобыльской аварии. Показано, что динамика средних значений эффективной дозы внешнего облучения жителей в этот период времени после чернобыльских выпадений хорошо описывается процессами, учитывающими радиоактивный распад и естественную миграцию радионуклидов цезия. Распределение индивидуальных доз внешнего облучения жителей населенных пунктов, нормированное на среднее значение дозы в населенных пунктах, соответствует логарифмически нормальному закону с устойчивыми во времени параметрами: геометрическим средним значением 0,9 и геометрическим стандартным отклонением 1,5, что позволяет, в частности, прогнозировать значение дозы у критической группы населения или для репрезентативного индивидуума (a representative person). Сравнение значений средних эффективных доз внешнего облучения у жителей населенных пунктов, оцененных на основании результатов двух различных методов измерений (индивидуальных доз с использованием термолюминесцентных дозиметров и измерений мощностей доз в воздухе в различных локациях населенных пунктов), показало их хорошее согласие через 17 лет после аварии. В двух населенных пунктах, где проводились измерения в 2003 г., относительные различия значений средних эффективных доз не превышали $12 \%$. Это позволяет и в дальнейшем использовать ранее разработанную модель внешнего облучения для оценки доз унаселения, проживающего на территориях, загрязненных вследствие чернобыльской аварии.
\end{abstract}

Ключевые слова: чернобыльская авария, внешнее облучение населения, эффективная доза, мощность дозы гамма-излучения, термолюминесиентные дозиметры.

Vladislav Yu. Golikov

Saint-Petersburg Research Institute of Radiation Hygiene after Professor P.V. Ramzaev

Address for correspondence: Mira str., 8, Saint-Petersburg, 197101; E-mail: sg235@rambler.ru

Голиков Владислав Юрьевич

Санкт-Петербургский научно-исследовательский институт радиационной гигиены имени профессора П.В. Рамзаева

Адрес для переписки: 197101, Россия, Санкт-Петербург, ул. Мира, д. 8; E-mail: sg235@rambler.ru 


\section{Introduction}

For the first time systematic studies of the doses of external exposure of the population as a result of large-scale releases of radioactive materials into the environment were performed after the Chernobyl accident on the territories of the former Soviet Union, later the Russian Federation, Ukraine and Belarus. Most of the measurements were performed in the 1986-1993 period and the main results were published during the first 10 years after the accident [1-5].

Two approaches and the two corresponding sets of measurement results were used for the assessment of the effective dose from external exposure to the population living on the territories contaminated after the Chernobyl accident:

the gamma dose rates in air in different location of the anthropogenic environment;

individual doses to representatives of different population groups measured by thermoluminescent dosimetry technique (TLD-method).

In the first case, the evaluation of the effective dose for any period of time was performed using a dosimetric model of external exposure of the population living in a contaminated area [6]. Such model relates the source term information, radionuclide concentrations in the environment, or gamma dose rates in air to the doses of people and in addition to the intensity of external radiation fields (measured values of gamma dose rates in the environment) also includes specific parameters that are not directly related to the radiation accident, but which largely determine the accumulation of the dose over a long period of time. First of all, they include characteristics of the behavior of various social and age population groups in the contaminated area (occupancy times), protective properties of residential and industrial premises.

The individual dose measurement allows accurately considering all factors that influence a dose of external exposure to the residents of contaminated areas, due to the fact that the dosimeter is being worn on the surface of the human body during the whole period of measurement. The sample of adult residents in the settlement, as a rule, included the representatives of three population groups living in different types of houses (one-story wooden or one-story brick houses and multi-story houses): mainly working indoors (group 1 - employees, sellers, teachers, etc.) mainly working outdoors (group 2 - agricultural workers) and pensioners.

As a rule, the number of people in the sample was not less than 30-50 which made it possible to reliably estimate the parameters of the individual dose distribution of external radiation among the residents of settlement. A sufficiently long period of dosimeters wearing (usually within a month) excludes the influence of the differences in the behavior regimes of people in separate days (weekends and work days, rainy and sunny days, etc.) on the results of measurements.

Nevertheless, when performing the individual dose measurements, a number of subjective and objective difficulties may arise, that affects the reliability or inaccuracy of the obtained results:

In the violation of the instructions not all residents constantly wear the individual dosimeter and some residents deliberately distorted the results of the measurements by placing dosimeters in places with an abnormally high dose rate (for example, under watercourses).

\section{Введение}

Впервые систематические исследования доз внешнего облучения населения в результате крупномасштабных выбросов радиоактивных веществ в окружающую среду были выполнены после Чернобыльской аварии на территориях бывшего Советского Союза (позже Российской Федерации, Украины и Беларуси). Большинство измерений было выполнено в период 1986-1993 гг., и основные результаты были опубликованы в течение первых 10 лет после аварии [1-5].

Для оценки эффективной дозы внешнего облучения населения, проживающего на территориях, загрязненных после аварии на ЧАЭС, использовали два подхода и соответствующие им различные наборы результатов измерений:

- мощностей доз гамма-излучения в воздухе в отдельных локациях антропогенной среды;

- индивидуальных доз внешнего излучения у представителей различных групп населения, полученных методом термолюминесцентной (ТЛ) дозиметрии.

В первом случае оценку величины эффективной дозы за какой-либо промежуток времени проводили с использованием дозиметрической модели формирования дозы внешнего облучения населения, проживающего на загрязненной территории [6]. Эта модель, помимо интенсивности полей внешнего излучения (измеренные значения мощностей доз внешнего излучения в окружающей среде), включает также специфические параметры, прямо не связанные с радиационной аварией, но в значительной степени определяющие накопление дозы за длительный промежуток времени. В первую очередь к ним относят характеристики поведения различных социальных и возрастных групп населения на загрязненной территории, защитные свойства жилых и производственных помещений.

Измерение индивидуальных доз позволяет наиболее точно учесть все факторы, влияющие на формирование дозы внешнего облучения у жителей загрязненных территорий, т.к. ТЛ-дозиметр в течение всего периода измерений носится на поверхности тела человека. Выборка взрослых жителей в НП включала представителей трех групп населения, проживающих в домах различного типа (одноэтажных деревянных или каменных домах, многоэтажных домах): работающих преимущественно внутри помещений (группа 1 - служащие, продавцы, учителя и т. п.) работающих преимущественно вне помещений (группа 2 сельскохозяйственные работники) и пенсионеров. Как правило, количество жителей НП в выборке составляло не менее 30-50 человек, что позволяло достоверно оценить параметры распределения индивидуальной дозы внешнего излучения. Достаточно длительный период ношения дозиметров (как правило, в течение месяца) исключал влияние на результаты измерений различий в режимах поведения людей в отдельные дни (выходные и рабочие дни, дождливые и солнечные дни и т.п.). Тем не менее, при проведении измерений индивидуальных доз внешнего излучения у жителей загрязненных территорий возникал ряд субъективных и объективных трудностей, влиявших на достоверность или погрешность получаемых результатов:

- в нарушение инструкций, не все жители постоянно носили индивидуальные дозиметры, а некоторые жители умышленно искажали результаты измерений, помещая дозиметры в места с аномально высокой мощностью дозы (например, под водостоки); 
It is difficult to perform their reliable separation when the value of the Chernobyl dose component is comparable to the dose of natural radiation. Hence the individual dose measurements were performed in those settlements where the average surface activity of the long-lived ${ }^{137} \mathrm{Cs}$ in the soil was not less than $555 \mathrm{kBq} \mathrm{m}^{-2}$.

The results of the doses analysis to the inhabitants in the most contaminated Bryansk region of the Russian Federation in 1989-1994 were published in [7] and showed good agreement between the estimates of the effective doses due to external exposure which were performed according to both approaches (the difference in the mean doses of settlement residents did not exceed 1.5 times with a confidence level of $95 \%$ ).

Later in 2003 (17 years after the accident and 10 years after the end of the main series of measurements in 1993) within the international Project RER/9/074 under the auspices of the IAEA, new field studies of the radiation situation in two villages of Bryansk region - Smyalch and Veprin were performed. In the course of these studies, in particular, gamma-radiation dose rates in the different locations of the settlements and individual doses at residents using TL dosimeters were measured. It was the last successful event for measuring individual doses for residents of contaminated areas by TL dosimetry. Later, none of the attempts to repeat the measurements of individual doses at residents of contaminated areas was successful because of their reluctance to participate in measurements.

\section{The objectives of this paper were:}

Analysis of the long-term dynamics of the distribution characteristics of the effective dose due to external exposure among the residents of rural settlements after a large-scale release of radioactive materials into the environment assessed by the method of the individual dose measurements.

Comparison of average effective dose values due to external exposure of inhabitants in the remote period after the Chernobyl accident (17 years later), obtained by the method of the TLD measurements of individual doses and on the basis of measurements of dose rates.

The paper is mainly based on the materials of long-term dosimetric studies in the two rural settlements (Smyalch and Veprin) of Bryansk Region of the Russian Federation.

\section{Materials and methods}

Within the framework of the international project RER/9/074 selective radiological surveys in settlements Veprin and Smyalch (the surface ${ }^{137} \mathrm{Cs}$ activity in soil on the settlements territory were $866 \mathrm{kBq} \mathrm{m}^{-2}$ and $646 \mathrm{kBq} \mathrm{m}^{-2}$ as of 26.04.86) in the Bryansk region were performed by experts of the St. Petersburg Research Institute of Radiation Hygiene in July 2003.

Measurements of individual external doses in the settlement residents were performed with the use of the TLD technique with LiF-detectors (DTG-4 LiF:Mg,Ti; monocrystals of 5 $\mathrm{mm}$ in diameter and $1 \mathrm{~mm}$ in thickness). Each individual dosimeter with a wall thickness from tissue-equivalent plastics of $1 \mathrm{~g} \cdot \mathrm{cm}^{-2}$ contained two detectors. The detectors were calibrated in the field of the reference ${ }^{137} \mathrm{Cs}$ source at the Institute of Metrology in St. Petersburg. The basic relative error of the measurement did not exceed $\pm 15 \%$ per detector with a confidence level of $95 \%$. The detection limit defined as the smallest value of dose that can be detected at a specified (95\%) confidence level was determined to be $20 \mu \mathrm{Gy}$.
- при значении чернобыльского компонента дозы, сравнимом с дозой природного излучения, трудно выполнить их достоверное разделение, поэтому, как правило, измерения проводили в тех НП, где средняя поверхностная активность долгоживущего радионуклида ${ }^{137} \mathrm{Cs}$ в почве составляла не менее 555 кБк м².

Результаты анализа доз внешнего облучения населения в 1989-1994 гг., проживающего в наиболее загрязненных районах Брянской области РФ, были опубликованы в [7] и показали хорошее согласие оценок эффективных доз, выполненных согласно обоим подходам (расхождение значений средних доз у жителей НП не превышало 1,5 раз с доверительной вероятностью 95\%).

Позже, в 2003 г. (т.е. через 17 лет после аварии и через 10 лет после окончания в 1993 г. основной серии измерений) в рамках международного проекта RER/9/074 под эгидой МАГАТЭ были проведены новые полевые исследования радиационной обстановки в двух селах Брянской области (Смяльч и Веприно). В ходе этих исследований, в частности, проводились измерения мощностей доз гамма-излучения в различных локациях НП и индивидуальных доз у жителей с помощью ТЛ-дозиметров. Это была последняя удачная компания по измерению индивидуальных доз у жителей загрязненных территорий методом ТЛ-дозиметрии. Позже ни одна из попыток повторить измерения индивидуальных доз у жителей не увенчалась успехом из-за их нежелания участвовать в измерениях.

\section{Целями настоящей статьи являлись:}

- проведение анализа долгосрочной динамики характеристик распределения эффективной дозы внешнего облучения у жителей после крупномасштабного выброса радиоактивных веществ в окружающую среду;

- сравнение средних значений эффективной дозы внешнего облучения у жителей в отдаленный период времени после аварии на ЧАЭС (через 17 лет), полученных методом измерений индивидуальных доз и на основе измерений мощностей доз в окружающей среде.

Материалы, представленные в работе, в основном основаны на результатах долговременных измерений, выполненных в селах Смяльч и Веприно Брянской области Российской Федерации.

\section{Материалы и методы}

В рамках международного проекта RER/9/074 радиологические обследования в НП Веприно и Смяльч Брянской области (значение поверхностной активности радионуклида ${ }^{137} \mathrm{Cs}$ в почве на территории этих НП составляло 866 кБк м ${ }^{-2}$ и 646 кБк м-2 на 26.04.86 г.) были проведены специалистами Санкт-Петербургского НИИ радиационной гигиены в июле 2003 г. Измерения индивидуальных доз внешнего излучения проводились с помощью ТЛ-детекторов из фтористого лития (ДТГ-4; LiF:Mg,Ti; монокристаллы 5 мм диаметром и 1 мм толщиной). Каждый индивидуальный дозиметр с толщиной стенок из тканеэквивалентной пластмассы 1 г·см ${ }^{-2}$ содержал два детектора. Детекторы калибровали в поле образцового источника ${ }^{137} \mathrm{Cs}$ во ВНИИМ им. Д.М. Менделеева в г. Санкт-Петербурге. Основная относительная ошибка измерения не превышала $\pm 15 \%$ при доверительной вероятности 95\%. Минимальная доза гамма-излучения, регистрируемая с доверительной вероятностью 95\%, составляла 20 мкГр. 
100 dosimeters were distributed in Veprin and 108 dosimeters - in Smyalch. 12 background dosimeters were used to monitor the background dose accumulated by the working dosimeters during the time since the distribution to the moment of their readout. The dosimeters were collected exactly in one month. 88 dosimeters were collected in Veprin (12 were lost), in Smyalch - 98 dosimeters (10 were lost).

The dose accumulated by each dosimeter during the month $D_{\text {ind }}$ was calculated using the equation 1:

$$
D_{\text {ind }}=\frac{0.5 \cdot\left(q_{1}+q_{2}\right)}{K}, \mu \mathrm{Gy}(1)
$$

where $0.5 \cdot\left(q_{1}+q_{2}\right)$ is the average value of readings of two detectors located in one dosemeter, $\mathrm{nC} ; \mathrm{K}$ is the calibration factor, $\mathrm{nC} \mu \mathrm{Gy}^{-1}$. When assessing individual doses in each settlement resident, the value of the background dose determined with the results of measurements of the 12 background dosemeters was subtracted from the value calculated with formula (1).

To assess the individual dose in residents, we used the dosemeters readings $D_{\text {ind }}$, if they satisfied the following conditions:

for Veprin: $50 \mathrm{mSv}<D_{\text {ind }}<260 \mathrm{mSv}$,(2)

for Smyalch: $25 \mathrm{mSv}<D_{\text {ind }}<180 \mathrm{mSv}$

The lower value of the recorded individual dose corresponded to its monthly value at permanent staying of a person indoors (at home). The upper value corresponded to its monthly value if a person stayed $75 \%$ of time on a virgin plot of soil, and $25 \%$ of time - at home. The corresponding numeric values of monthly doses were assessed on the basis of the data of measurements of dose rates indoors and above virgin soils in each of the surveyed settlement. The measured values of $D_{\text {ind }}$ were transferred to the effective doses with the use of the transfer factor $0.9 \mathrm{~Sv} \mathrm{~Gy}{ }^{-1}$ established on the basis of phantom measurements [8].

Gamma radiation dose rate was determined in typical locations within and outside the settlements. Firstly were surveyed areas of individual plots: residential building (wooden or brick house), kitchen-garden, yard, and adjacent part of the street. Besides that, in the settlement we chose and surveyed "virgin plots" which were open areas with grass cover, not ploughed after 1986. We also surveyed public buildings (the club, the shop, the health cabinet, and the post-office). Outside the settlement, we performed measurements in nearest forests and on pastures (meadows). Preliminary, we determined that these objects belong to the area of the given settlement and are used by local residents for pasturing cattle, hay harvesting, gathering mushrooms and berries, and for recreation.

Measurement of the gamma radiation dose rate was performed at the height of $1 \mathrm{~m}$ above the ground ( $1 \mathrm{~m}$ above the floor surface in premises) with the EL-1119 gamma dosemeter (produced by ATOMTEKH, Belarus) allowing measuring dose rates and gamma radiation dose with the energy in the range of $0.025-3 \mathrm{MeV}$ at the dose rate from $50 \mathrm{nGy} \mathrm{h}^{-1}$ to $1 \mathrm{~Gy}$ $h^{-1}$. The basic relative error of the measurement is $\pm 20 \%$. The time of measurement was chosen in each location in such a way that the relative statistical error of the average dose rate value was not greater than $10 \%$.

To assess the contribution of the dosemeter background in its readings and the response to the space radiation, preliminarily were performed special measurements above the surface of big water objects (deep lakes) at the distance from the shore not
В НП Веприно было выдано 100 дозиметров, в НП Смяльч - 108. Для контроля фоновой дозы, накопленной рабочими дозиметрами за время, прошедшее с момента их отжига до момента их высвечивания, использовали 12 фоновых дозиметров. Сбор дозиметров производился ровно через месяц после выдачи. Всего в Веприно было собрано 88 дозиметров (12 утрачено), в Смяльче - 98 (10 утрачено).

Накопленная каждым дозиметром за месяц доза $D_{\text {инд }}$ рассчитывалась по формуле:

$$
D_{\text {инд }}=\frac{0,5 \cdot\left(q_{1}+q_{2}\right)}{K}, \text { мк3в (1) }
$$

где: 0,5 $\left(q_{1}+q_{2}\right)-$ среднее значение показаний двух детекторов, размещенных в одном дозиметре, нКл; К - калибровочный коэффициент, нКл мкЗв ${ }^{-1}$. При оценке индивидуальных доз каждого жителя НП, обусловленной радиоактивными выпадениями, из рассчитанной по формуле (1) дозы вычиталось среднее значение фоновой дозы, определенное по результатам измерений 12 фоновых дозиметров.

Показания дозиметров $D_{\text {инд }}$ использовали для оценки индивидуальной дозы жителей, если они удовлетворяли следующим условиям:

для НП Веприно: 50 мкЗв $<D_{\text {ннд }}<260$ мкЗв,(2)

для НП Смяльч: 25 мкЗв $<D_{\text {инд }}<180$ мкЗв.

Нижнее значение дозы соответствовало ее месячному значению при постоянном пребывании человека в помещении (жилом здании). Верхнее значение соответствовало ее месячному значению при таком режиме поведения человека, когда он 75\% времени находится на целинном участке почвы и 25\% времени - в жилом помещении. Соответствующие численные значения месячных доз были оценены на основании данных измерений мощностей доз в помещениях и над целинными участками в каждом обследованном НП. При переходе от измеренных значений $D_{\text {инд }}$ к значению эффективной дозы использовали коэффициент 0,9 Зв Гр ${ }^{-1}$, установленный с помощью фантомных измерений [8].

Измерения мощности дозы гамма-излучения в воздухе выполнялисьв типичных локацияхвнутри ивнеНП. Во-первых, обследовали ареалы индивидуальных подворий: а) жилое здание (деревянный или каменный дом), б) огород, в) двор, д) прилегающий участок улицы. Кроме того, внутри НП выбирались и обследовались «целинные участки», представлявшие собой открытую территорию, имеющую травяное покрытие и не подвергавшуюся обработке после 1986 г. Обследованы были и общественные здания (клуб, магазин, медпункт, почта). За пределами НП измерения были выполнены в близлежащих лесах и на пастбищах (лугах). Предварительно было установлено, что эти объекты принадлежат к ареалу данного НП и используются местными жителями для выпаса скота, заготовки сена, сбора грибов, ягод и отдыха.

Измерение мощности дозы гамма-излучения проводили на высоте 1 м от поверхности земли (1 м от поверхности пола в помещениях) с помощью дозиметра гаммаизлучения EL-1119 (производство фирмы «ATOMTEX», Беларусь). Приборы данного класса позволяют измерять мощность кермы в воздухе (нГр час $\left.{ }^{-1}\right)$ гамма-излучения с энергией в диапазоне 0,025-3 МэВ при значениях от 50 нГр час ${ }^{-1}$ до 1 Гр час ${ }^{-1}$. Время измерения в каждой точке выбиралось таким образом, чтобы относительная статистическая погрешность среднего значения мощности дозы не превышала $10 \%$. 
less than $100 \mathrm{~m}$. The equivalent of the own background and the response to the cosmic radiation in this type of devices is $10-20$ nGy $\mathrm{h}^{-1}$. To assess the Chernobyl component of the gamma radiation dose rate, we subtracted this value and the value of the terrigenic radiation contribution (20 - $50 \mathrm{nGy} \mathrm{h}^{-1}$ in different location of settlement in Bryansk region [7, 9]) from the value of its readings. Thus, the presented results correspond to the dose rate of the Chernobyl component of gamma radiation.

The value of the monthly external effective dose to representatives of the $i$-th population group on the basis of the measurement of dose rates in different locations of a settlement $E_{i}$ was calculated using the equation 3:

$$
E_{i}=10^{-3} \cdot 720 \cdot K_{i}^{E} \cdot \sum_{j}\left(D_{j}-D_{j o}\right) \cdot p_{i j}, \mu \text { Sv (3) }
$$

where $K_{i}^{E}$ is conversion coefficient from air dose on the height of $1 \mathrm{~m}$ to the effective dose (for the adult population was taken equal to $\left.0.75 \mathrm{~Sv} \mathrm{~Gy}^{-1}[4,6]\right)$;

$p_{i j}$ is occupancy factor determining the proportion of time during which representatives of the $i$-th population group are in the $j$-th location of the settlement $[4,6]$ (see. Table 1);

$D_{j}\left(\mathrm{nGy} \mathrm{h}^{-1}\right)$ - the measured value of the total dose rate in the air at the height of $1 \mathrm{~m}$ in location $j$;

$D_{j o}\left(n G y h^{-1}\right)$ is the value of the dose rate due to the background response of the device and contributions to its readings of cosmic and terrigenic radiation in the j-th location.

720 is the number of hours in a month;

$10^{-3}$ is the transfer factor from nGy to $\mu \mathrm{Gy}$.

\section{Results}

Results of measurements of gamma dose rates at typical locations in villages Veprin and Smyalch are summarized in Tables 2 and 3.

Considering the gamma dose rates at typical locations of the settlements and lifestyle (occupancy factors) of the inhabitants the monthly (July) average effective dose of external exposure are:
Для оценки вклада в показания дозиметра его собственного фона и отклика на космическое излучение предварительно проводились специальные измерения над поверхностью водных объектов (глубокие озера) на расстоянии от берега не менее 100 м. Эквивалент собственного фона и отклика на космическое излучение этого типа приборов составляет 10-20 нГр час-1. Для оценки чернобыльского компонента мощности дозы гамма-излучения эта величина вместе с вкладом терригенного излучения (20-50 нГр час-1 в Брянской области $[7,9])$ вычиталась из его показаний.

Значение месячной эффективной дозы внешнего облучения у представителей і-й группы населения на базе результатов измерений мощностей доз в различных локациях НП $\mathrm{E}_{i}$ рассчитывалась с использованием выражения:

$$
E_{i}=10^{-3} \cdot 720 \cdot K_{i}^{E} \cdot \sum_{j}\left(D_{j}-D_{j o}\right) \cdot p_{i j} \text {, мк3в (3) }
$$

где $K_{i}^{E}$ - коэффициент перехода от дозы в воздухе на высоте 1 м к эффективной дозе (для взрослого населения принимался равным 0,75 Зв Гр⿰ $\left.{ }^{-1}[4,6]\right)$;

$p_{i j}$ - фактор поведения, представляющий собой долю времени, в течение которого представители і-й группы населения находятся в ј-й локации НП [4, 6] (табл. 1);

$D_{j}\left(\right.$ нГр час $\left.^{-1}\right)$ - измеренное значение суммарной мощности дозы в воздухе на высоте 1 м в локации $j$;

$D_{j o}\left(\right.$ нГр час $\left.{ }^{-1}\right)$ - значение мощности дозы, обусловленное фоновым откликом прибора и вкладами в его показания космического и терригенного излучений в ј-й локации.

720 - количество часов в месяце;

$10^{-3}$ - коэффициент перевода нГр в мкГр.

\section{Результаты и обсуждение}

Результаты измерений мощностей доз гаммаизлучения в воздухе в типичных локациях НП Веприно и Смяльч представлены в таблицах 2 и 3 соответственно.

Table 1

\section{Occupancy factors in summer season for different rural population groups}

[Таблица 1

\begin{tabular}{|c|c|c|c|}
\hline $\begin{array}{c}\text { Location } \\
\text { [Тип локации] }\end{array}$ & $\begin{array}{c}\text { Group 1 } \\
\text { [Группа 1] }\end{array}$ & $\begin{array}{c}\text { Group } 2 \\
\text { [Группа 2] }\end{array}$ & $\begin{array}{c}\text { Pensioners } \\
\text { [Пенсионеры] }\end{array}$ \\
\hline \multicolumn{4}{|c|}{$\begin{array}{c}\text { Living area } \\
\text { [Жилая зона] }\end{array}$} \\
\hline $\begin{array}{l}\text { Inside houses } \\
\text { [B помещении] }\end{array}$ & 0.42 & 0.42 & 0.56 \\
\hline $\begin{array}{c}\text { Outside houses } \\
\text { [Вне помещения] }\end{array}$ & 0.28 & 0.20 & 0.40 \\
\hline \multicolumn{4}{|l|}{$\begin{array}{c}\text { Work area } \\
\text { [Рабочая зона] }\end{array}$} \\
\hline $\begin{array}{l}\text { Building } \\
\text { [Зданиe] }\end{array}$ & 0.23 & 0.08 & 0.00 \\
\hline $\begin{array}{c}\text { Work yard } \\
\text { [Рабочий двор] }\end{array}$ & 0.04 & 0.07 & 0.00 \\
\hline $\begin{array}{l}\text { Plough field } \\
\text { [Пахота] }\end{array}$ & 0.01 & 0.18 & 0.00 \\
\hline \multirow[t]{2}{*}{$\begin{array}{l}\text { Virgin land } \\
\text { [Целина] }\end{array}$} & 0.00 & 0.03 & 0.00 \\
\hline & \multicolumn{2}{|c|}{ Зона отдыха } & \\
\hline $\begin{array}{l}\text { Forest, meadow } \\
\text { [Лес, луг] }\end{array}$ & 0.02 & 0.02 & 0.04 \\
\hline
\end{tabular}

Значения фактора поведения в летний сезон для разных групп сельского населения] 
Results of measurements of gamma dose rate at typical locations in the village Veprin in July 2003

Table 2

[Таблица 2

Результаты измерений мощностей доз гамма-излучения в воздухе в типичных локациях НП Веприно в июле 2003 г.]

\begin{tabular}{|c|c|c|c|}
\hline \multirow{2}{*}{$\begin{array}{l}\text { Type of location } \\
\text { [Тип локации] }\end{array}$} & \multirow{2}{*}{$\begin{array}{c}\text { Number of } \\
\text { measurements } \\
\text { [Число измерений] }\end{array}$} & \multicolumn{2}{|c|}{ 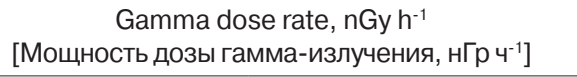 } \\
\hline & & $\begin{array}{c}\text { Mean } \\
\text { [Среднее] }\end{array}$ & $\begin{array}{l}\text { St. dev. } \\
\text { [Ст. откл.] }\end{array}$ \\
\hline $\begin{array}{c}\text { One-story wooden house } \\
\text { [Одноэтажный деревянный дом] }\end{array}$ & 22 & 71 & 15 \\
\hline $\begin{array}{c}\text { One-story brick house } \\
\text { [Одноэтажный каменный дом] }\end{array}$ & - & - & - \\
\hline $\begin{array}{c}\text { Public buildings } \\
\text { [Общественные здания] }\end{array}$ & 3 & 19 & 8 \\
\hline $\begin{array}{l}\text { Kitchen garden + garden } \\
\text { [Огород, сад] }\end{array}$ & 24 & 353 & 54 \\
\hline $\begin{array}{c}\text { Work yard } \\
\text { [Рабочий двор] }\end{array}$ & 48 & 235 & 81 \\
\hline $\begin{array}{l}\text { Street } \\
\text { [Улица] }\end{array}$ & 24 & 114 & 36 \\
\hline $\begin{array}{l}\text { Plough field } \\
\text { [Пашня] }\end{array}$ & 3 & 245 & 52 \\
\hline $\begin{array}{l}\text { Virgin land inside of village } \\
\text { [Целина внутри НП] }\end{array}$ & 22 & 479 & 113 \\
\hline $\begin{array}{c}\text { Virgin land outside of village } \\
\text { [Целина вне НП] }\end{array}$ & 30 & 543 & 186 \\
\hline $\begin{array}{l}\text { Forest } \\
{[\text { Jec }]}\end{array}$ & 31 & 628 & 82 \\
\hline \multicolumn{4}{|c|}{ Results of measurements of gamma dose rate at typical locations in the village Smyalch in July 2003} \\
\hline \multirow{2}{*}{$\begin{array}{l}\text { Type of location } \\
\text { [Тип локации] }\end{array}$} & \multirow{2}{*}{$\begin{array}{c}\text { Number of } \\
\text { measurements } \\
\text { [Число измерений] }\end{array}$} & \multicolumn{2}{|c|}{$\begin{array}{l}\text { Gamma dose rate, nGy h-1 } \\
\text { [Мощность дозы гамма-излучения, нГр ч - }]\end{array}$} \\
\hline & & $\begin{array}{c}\text { Mean } \\
\text { [Среднее] }\end{array}$ & $\begin{array}{l}\text { St. dev. } \\
\text { [Ст. откл.] }\end{array}$ \\
\hline $\begin{array}{c}\text { One-story wooden house } \\
\text { [Одноэтажный деревянный дом] }\end{array}$ & 26 & 49 & 9 \\
\hline $\begin{array}{c}\text { One-story brick house } \\
\text { [Одноэтажный каменный дом] }\end{array}$ & 19 & 35 & 12 \\
\hline $\begin{array}{c}\text { Public buildings } \\
\text { [Общественные здания] }\end{array}$ & 3 & 24 & 3 \\
\hline $\begin{array}{l}\text { Kitchen garden + garden } \\
\text { [Огород, сад] }\end{array}$ & 41 & 240 & 44 \\
\hline $\begin{array}{l}\text { Work yard } \\
\text { [Рабочий двор] }\end{array}$ & 81 & 165 & 30 \\
\hline $\begin{array}{c}\text { Street } \\
\text { [Улица] }\end{array}$ & 35 & 102 & 28 \\
\hline $\begin{array}{l}\text { Plough field } \\
\text { [Пашня] }\end{array}$ & 11 & 227 & 29 \\
\hline $\begin{array}{l}\text { Virgin land inside of village } \\
\text { [Целина внутри НП] }\end{array}$ & 34 & 319 & 61 \\
\hline $\begin{array}{l}\text { Virgin land outside of village } \\
\text { [Целина вне НП] }\end{array}$ & 12 & 382 & 56 \\
\hline $\begin{array}{l}\text { Forest } \\
{[\text { Лec] }}\end{array}$ & 17 & 496 & 64 \\
\hline
\end{tabular}


- 79, 98 and $110 \mu \mathrm{Sv} \mathrm{mo}^{-1}$ for indoor group, outdoor group and pensioners of village Veprin living in wooden houses, respectively;

- 56, 74 and $75 \mu \mathrm{Sv} \mathrm{mo}^{-1}$ for indoor group, outdoor group and pensioners of village Smyalch living in wooden houses, respectively;

- 54, 71 and $71 \mu \mathrm{Sv} \mathrm{mo}^{-1}$ for indoor group, outdoor group and pensioners of village Smyalch living in brick houses, respectively.

Table 4 presents the results of the measurements of individual external doses of Veprin and Smyalch villages residents performed during the studies in July 2003.

Figure 1 presents the results of an estimate of the average monthly effective dose of external exposure at residents of Veprin and Smyalch villages performed after the Chernobyl accident during 1991-2003 based on the method of the individual dose measurements (TLD - measurements). The same figure shows the independent data of individual doses measurements in the village Veprin performed by Swedish colleagues in 1991-1998 [10], and for comparison, the results of 2003 estimates based on measurements of dose rates in air according to the relation (3).

The dynamics of the decrease in the average value of the dose due to external exposure of the inhabitants of both villages is mainly explained by the decay of the mixture of ${ }^{134} \mathrm{Cs}$ $+{ }^{137} \mathrm{Cs}$ radionuclides and their migration (redistribution) in the environment (anthropogenic and natural).

Taking this into account, as well as the fact that the measurements of individual doses of the inhabitants in these villages began 5 years after the fallout when the rapid migration processes either ended or had little effect on the dose of external exposure, the dependence of the average effective dose for residents $E_{a v}$ on time after the fallout $t$ was

$E_{a v}=a_{1} \cdot\left(1,49 \cdot \exp \left(-\frac{\ln 2}{2,06} \cdot t\right)+\exp \left(-\frac{\ln 2}{30} \cdot t\right)\right) \cdot \exp \left(-\frac{\ln 2}{50} \cdot t\right)(4)$

were: 2,06 у и 30 y are half-lives of ${ }^{134} \mathrm{Cs}$ и ${ }^{137} \mathrm{Cs}$, correspondingly;

the coefficient 1.49 considers the difference in the contributions of gamma radiation of ${ }^{134} \mathrm{Cs}$ and ${ }^{137} \mathrm{Cs}$ radionuclides to the value of the effective dose in an adult and the ratio of their activities in Chernobyl fallout;

50 years is half-life of a long-term component decrease in two exponential expression approximating the dynamics of
Используя значения измеренных мощностей доз гамма-излучения в воздухе в различных локациях НП (см. табл. 2 и 3) и значения факторов поведения населения в летний период времени из таблицы 1 , согласно соотношению (3), были рассчитаны значения эффективной месячной (июль) дозы у следующих групп населения:

- 79, 98 и 110 мкЗв мес ${ }^{-1}$ для группы 1, группы 2 и пенсионеров села Веприно, проживающих в деревянных одноэтажных домах, соответственно;

- 56, 74 и 75 мк3в мес ${ }^{-1}$ для группы 1, группы 2 и пенсионеров села Смяльч, проживающих в деревянных одноэтажных домах, соответственно, и 54, 71 и 71 мкЗв мес-1 для группы 1, группы 2 и пенсионеров того же села, проживающих в каменных одноэтажных домах, соответственно.

В таблице 4 представлены результаты обработки данных измерений индивидуальных доз внешнего облучения у жителей сел Веприно и Смяльч, выполненных в ходе исследований в июле 2003 г.

На рисунке 1 приведены результаты оценки средней месячной эффективной дозы внешнего облучения у жителей сел Веприно и Смяльч, выполненные после Чернобыльской аварии в течение 1991-2003 гг. на основе измерений индивидуальных доз (ТЛД-измерений). На этом же рисунке представлены независимые данные измерений индивидуальных доз внешнего излучения у жителей села Веприно, выполненные шведскими коллегами в 1991-1998 гг. [10], и для сравнения - результаты оценок 2003 г., выполненные на основе измерений мощностей доз в воздухе, согласно соотношению (3).

Динамика уменьшения среднего значения дозы внешнего облучения у жителей обоих сел, в основном, объясняется распадом смеси радионуклидов ${ }^{134} \mathrm{Cs}+{ }^{137} \mathrm{Cs}$ и их миграцией (перераспределением) в окружающей среде (антропогенной и природной). Учитывая это, а также тот факт, что измерения индивидуальных доз у жителей этих сел начались через 5 лет после выпадений, когда быстрые процессы миграции либо закончились, либо уже мало влияли на дозу внешнего излучения, зависимость среднего значения эффективной дозы у жителей $E_{a v}$ от времени после выпадений $t$ аппроксимировали следvюшим выражением: $E_{a v}=a_{1} \cdot\left(1,49 \cdot \exp \left(-\frac{\ln 2}{2,06} \cdot t\right)+\exp \left(-\frac{\ln 2}{30} \cdot t\right)\right) \cdot \exp \left(-\frac{\ln 2}{50} \cdot t\right)(4)$

где 2,06 года и 30 лет - периоды полураспада ${ }^{134} \mathrm{Cs}$ и ${ }^{137} \mathrm{Cs}$;

Table 4

Results of the measurements of individual external doses of Veprin and Smyalch villages residents in July 2003 (Chernobyl component)

Результаты измерений индивидуальных доз внешнего облучения у жителей сел Веприно и Смяльч в июле 2003 г. (чернобыльский компонент)]

\begin{tabular}{|c|c|c|c|}
\hline $\begin{array}{l}\text { Village } \\
{[\mathrm{H} \Pi]}\end{array}$ & $\begin{array}{l}\text { Number of measurements } \\
\text { [Количество измерений] }\end{array}$ & $\begin{array}{c}\text { Mean, } \mu \text { Sv mo-1 } \\
{\left[\text { [Среднее значение, мкЗв мес }{ }^{-1}\right]}\end{array}$ & $\begin{array}{c}\text { Std. dev., } \mu \text { Sv mo-1 } \\
\text { [Стандартное отклонение, мкЗв мес-1] }\end{array}$ \\
\hline $\begin{array}{c}\text { Veprin } \\
\text { [Веприно] }\end{array}$ & $64(100)^{*}$ & $113(51-244)^{\star *}$ & 49 \\
\hline $\begin{array}{l}\text { Smyalch } \\
\text { [Смяльч] }\end{array}$ & $73(108)^{\star}$ & $72(26-180)^{\star \star}$ & 36 \\
\hline
\end{tabular}

* number of the dosimeters handed out in village are indicated in parentheses; ** the minimum and maximum values of the doses passed through the filtration are indicated in parentheses (see relations (2)).

[ ${ }^{*}$ - в скобках указано количество выданных в НП дозиметров; ** - в скобках указано минимальное и максимальное значения доз, прошедших фильтрацию (см. соотношения (2))]. 


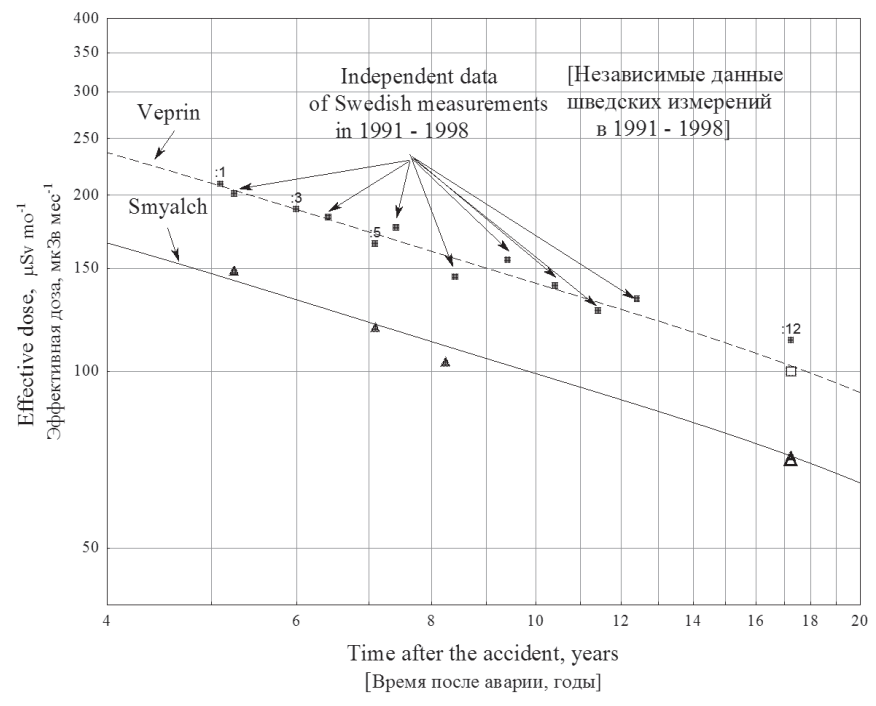

Fig.1. Dynamics of the monthly effective dose of external exposure at residents of Veprin and Smyalch settlements on the basis of individual dose measurements by TLD-method: black squares (1), (3), (5), (12) are the results of Russian measurements in Veprin; black triangles are the results of Russian measurements in Smyalch; white square is the result of effective dose estimate on the base of dose rate measurements in Veprin and white triangle is the result of effective dose estimate on the base of dose rate measurements in Smyalch.

[Рис. 1. Динамика месячной эффективной дозы внешнего облучения жителей сел Веприно и Смяльч на основании данных измерений индивидуальных доз методом ТЛД: черные квадраты - результаты российских измерений в с. Веприно; черные треугольники - результаты российских измерений в с. Смяльч; белый квадрат - результат оценки эффективной дозы на основе измерений мощностей доз в с. Веприно и белый треугольник - аналогичная оценка эффективной дозы в с. Смяльч]

gamma dose rate over virgin soil after the Chernobyl fallout due to natural migration of cesium [4];

$a_{1}$ - parameter estimated by the nonlinear regression method, $a_{1}=192 \mu \mathrm{Sv} \mathrm{mo}^{-1}$ и $a_{1}=135 \mu \mathrm{Sv} \mathrm{mo}^{-1}$ for settlements Veprin and Smyalch, correspondingly.

We note the following main features of the results presented in Fig. 1:

Dynamics of average effective dose values of residents due to external exposure during a period of 5 to 20 years after Chernobyl fallout is well described by the approximating expression (4), taking into account radioactive decay and natural migration of cesium radionuclides. Further decrease of the effective dose of external exposure will be due to the trivial law of ${ }^{137} \mathrm{Cs}$ radioactive decay and its possible further penetration into the soil.

The average effective dose of residents due to external exposure in both settlements in 2003 calculated on the basis of dose rates measurements in air are in good agreement with the results of TLD measurements of individual doses (relative differences of - $1 \%$ and $-12 \%$ for Smyalch and Veprin, respectively).

The distribution of individual doses of residents in each settlement was approximated by a logarithmically normal law. In both villages, this possibility was statistically justified by the criterion $\chi^{2}$. These distributions are presented in Figures 2 and 3 together with the distribution of external individual doses among the inhabitants of these settlements in 1993.

Previously performed analysis of the external dose distribution among residents based on more than 5,000 measurements of individual doses in 55 settlements of Bryansk region (1987-1993) showed that when normalized the individual dose to the average dose in the settlement (standardized distribution) it can be approximated logarithmically normal law with sufficiently stable parameters [6]. Thus the average value коэффициент 1,49 учитывает различие вкладов гамма-излучения радионуклидов ${ }^{134} \mathrm{Cs}$ и ${ }^{137} \mathrm{Cs}$ в значение эффективной дозы у взрослого человека и соотношение их активностей в чернобыльских выпадениях;

50 лет - полупериод уменьшения длинной компоненты в двухэкспоненциальной аппроксимации динамики мощности дозы внешнего излучения над целинной почвой из-за естественной миграции цезия [4];

$a_{1}$ - параметр, оцененный методом нелинейной регрессии, $\mathrm{a}_{1}=192$ мкЗв мес ${ }^{-1}$ и $\mathrm{a}_{1}=135$ мкЗв мес $^{-1}$ для НП Веприно и Смяльч соответственно.

Отметим следующие основные особенности результатов, представленных на рисунке 1.

Динамика средних значений эффективной дозы внешнего излучения у жителей в период времени 5-20 лет после чернобыльских выпадений хорошо описывается аппроксимирующим выражением (4), учитывающим радиоактивный распад и естественную миграцию радионуклидов цезия. Дальнейшее уменьшение эффективной дозы внешнего излучения будет связано с тривиальным законом радиоактивного распада радионуклида ${ }^{137} \mathrm{Cs}$ и возможного дальнейшего его заглубления в почву.

Значения средней эффективной дозы внешнего облучения жителей в обоих НП в 2003 г., рассчитанные на основе измерений мощностей доз в воздухе, хорошо согласуются с результатами ТЛД-измерений (относительные различия $-1 \%$ и - $12 \%$ для НП Смяльч и Веприно соответственно).

Распределения индивидуальных доз внешнего облучения жителей в каждом НП аппроксимировали логарифмически нормальным законом. В обоих селах такая возможность была статистически обоснована с помощью критерия $\chi^{2}$. Эти распределения представлены на рисунках 2 и 3 совместно с распределениями индивидуальных доз внешнего облучения у жителей этих НП в 1993 г. 


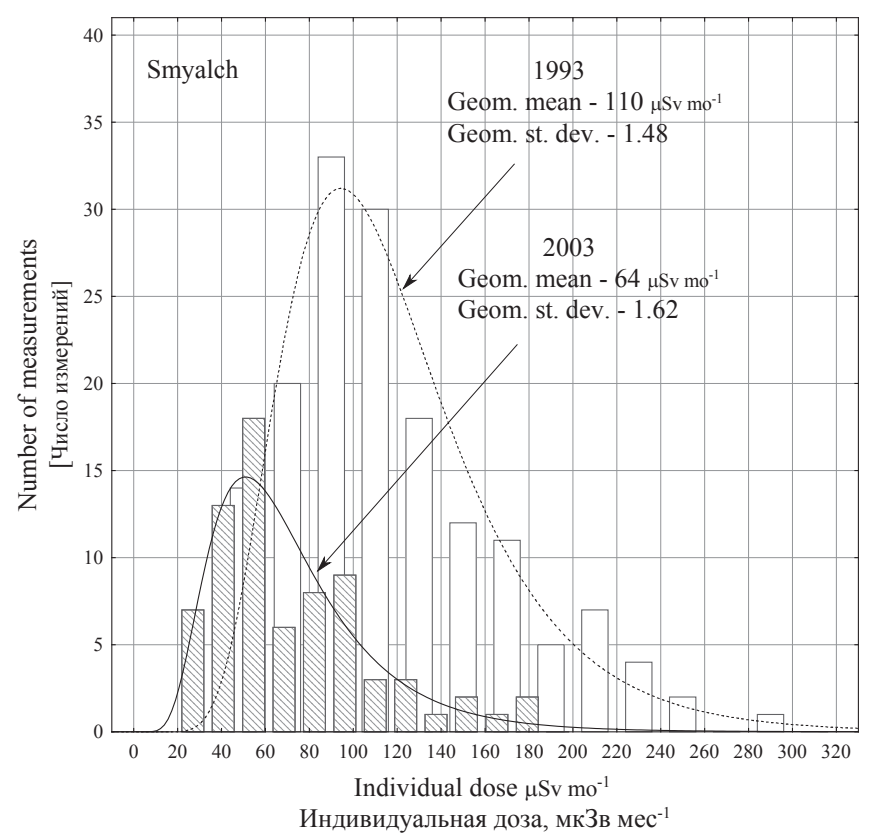

Fig.2. Distribution of individual external doses among the residents of Smyalch settlement in 1993 and 2003 [Рис. 2. Распределение индивидуальных доз внешнего облучения жителей села Смяльч в 1993 и 2003 гг.]

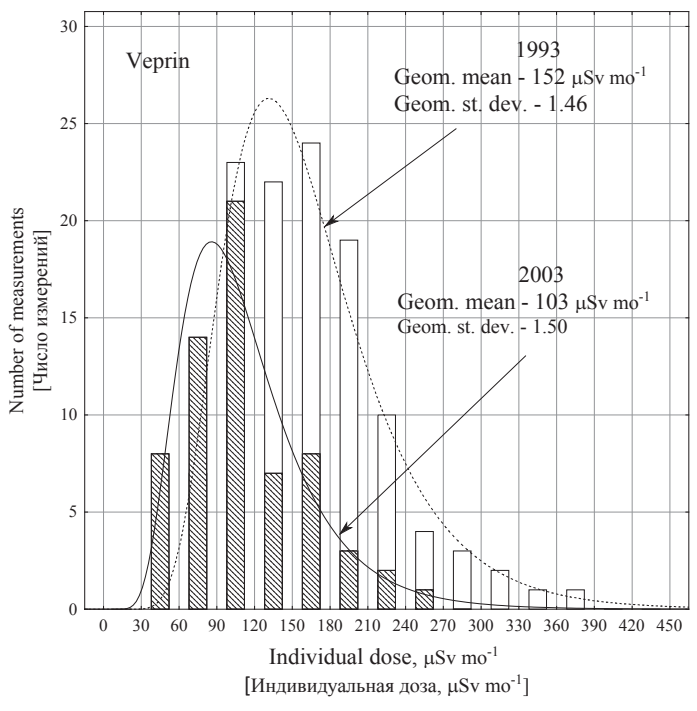

Fig. 3. Distribution of individual external doses among the residents of Veprin settlement in 1993 and 2003

[Рис. 3. Распределение индивидуальных доз внешнего облучения жителей села Веприно в 1993 и 2003 гг.]

of the geometric standard deviation of a standardized lognormal distribution in the 1987-1993 series of measurements (99 values) was $1.51 \pm 0.15$ (std. err.).

Parameters of standardized log-normal distributions of individual doses of external exposure among residents of Veprin and Smyalch villages in 2003 were estimated. The obtained results are presented in Table 5 which also gives similar values for the so-called "reference" lognormal distribution for individual doses of external exposure established in the 1987-1993 series of measurements. From a comparison of the presented data it can be seen that the parameters of the standardized log-normal distribution have practically not changed in the past 10 years.
Ранее проведенный анализ распределения дозы внешнего облучения у жителей на основе более чем 5 тысяч измерений индивидуальных доз в 55 НП Брянской области (1987-1993 гг.) показал, что при нормировании доз на среднее значение дозы в НП (стандартизованное распределение) его можно аппроксимировать логарифмически нормальным законом с достаточно устойчивыми параметрами [6]. Так, среднее значение геометрического стандартного отклонения стандартизованного логарифмически нормального распределения в серии измерений 1987-1993 гг. (99 значений) составило 1,51 \pm 0,15 (ст. ошибка среднего).

Были оценены параметры стандартизованных логарифмически нормальных распределений индивиду- 
Parameters of standardized (normalized on the mean dose in the village) log-normal distributions of individual doses among inhabitants of villages Smyalch and Veprin

Параметры стандартизованного (нормированного на среднюю дозу в НП) логарифмически нормального распределения индивидуальных доз среди жителей сел Веприно и Смяльч]

Parameters of standardized log-normal distributions

[Параметры стандартизованного логарифмически нормального распределения]

$\begin{array}{cc}\text { Geometric mean } & \text { Geometric st. dev. } \\ \text { [Геометрическое среднее] } & \text { [Геометрическое стандартное откл.] }\end{array}$

Reference distribution

[Референтное распределение]

\begin{tabular}{|c|c|c|}
\hline (1987-1993) & 0.90 & 1.51 \\
\hline $\begin{array}{c}\text { Veprin } \\
\text { (July 2003) } \\
\text { Июль 2003г.] }\end{array}$ & 0.92 & 1.50 \\
\hline $\begin{array}{l}\text { Smyalch } \\
\text { (Јuly 2003) } \\
\text { Июль 2003 г.] }\end{array}$ & 0.89 & 62 \\
\hline
\end{tabular}

This allows estimating the dose in the critical population group defined as the average dose in $10 \%$ of the settlement residents who have the highest individual doses compared to the rest of the residents, based on the value of the average population dose in the settlement [11]. According to the parameters of the log-normal distribution presented above, almost the entire (99.9\%) range of the "individual dose/average dose in settlement" ratio ( $K_{D}^{u н d}$ ) is limited by a factor of 3.2. The average value of $K_{D}^{u н д}$ for a group of residents

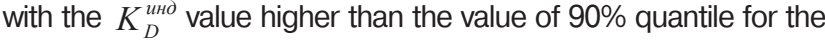
individual dose distribution is 1.85 . If the proposed ICRP concept of a representative person is used [12] then it is necessary to use 95\% quantile of the individual dose distribution for the limitation of the population exposure. For the exposure situation considered here it corresponds to the $K_{D}^{u н d}$ value equal to 1.75 , which is only slightly different from the value estimated above (1.85) according to the approach adopted in Russia [11].

\section{Conclusion}

An analysis of the dynamics of individual doses of external exposure among the population living for almost 20 years in the territories affected to radioactive contamination as a result of the Chernobyl accident showed the following:

Dynamics of average effective dose of the external exposure of inhabitants during a period of 5 to 20 years after Chernobyl fallout is well described by processes that take into account radioactive decay of ${ }^{134} \mathrm{Cs}+{ }^{137} \mathrm{Cs}$ radionuclides and their natural migration with long component of half-life equal of a 50 -years.

The distribution of individual doses of external exposure among residents, normalized to the average dose in the settlement corresponds to a logarithmically normal law with time-stable parameters (geometric mean and geometric standard deviation), which allows, in particular, to predict the dose of the critical group of population or for a representative person according to the new concept of ICRP [11].

Comparison of the mean effective dose of external exposure at settlement residents estimated on the basis of the results of two different measurement technologies (using TLD-method and measurements of dose rates in air in various settlement locations) showed their good agreement 17 years after the fallout. In two settlements, where measurements were made in 2003 , the relative differences in mean effective doses did not альных доз внешнего облучения жителей сел Веприно и Смяльч в 2003 г. Полученные результаты представлены в таблице 5, где также приведены аналогичные значения для так называемого "референтного" логарифмически нормального закона распределения индивидуальных доз внешнего облучения, установленные в серии измерений 1987-1993 гг. Из сравнения приведенных данных видно, что параметры стандартизованного логарифмически нормального распределения практически не изменились за прошедшие 10 лет. Это позволяет, зная значение средней дозы в НП, оценить дозу в критической группе населения, определяемую как средняя доза у $10 \%$ жителей НП, имеющих наибольшие по сравнению с остальными жителями индивидуальные дозы облучения [11]. При указанных выше параметрах логарифмически нормального распределения, практически весь (99,9\%) диапазон значений отношения Индивидуальная доза/Средняя доза в НП" ( $K_{D}^{u н d}$ ) ограничен сверху значением 3,2. При этом среднее значение $K_{D}^{u н д}$ для группы жителей, у которой $K_{D}^{u н д ~ п р е-~}$ вышает 90\% квантиль в распределении индивидуальной дозы, равно 1,85. Если же использовать предложенную МКРЗ концепцию репрезентативного индивидуума [12], то для ограничения облучения населения необходимо использовать 95\% квантиль в распределении индивидуальной дозы. В рассматриваемой нами ситуации внешнего

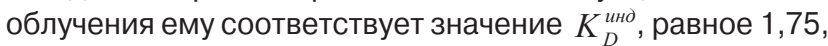
что незначительно отличается от значения $K_{D}^{u н д}$, оцененного выше согласно подходу, принятому в России [11].

\section{Заключение}

Анализ динамики индивидуальных доз внешнего облучения населения, проживающего в течение почти 20 лет на территориях, подвергшихся радиоактивному загрязнению в результате Чернобыльской аварии, показал следующее:

1. Динамика средних значений эффективной дозы внешнего облучения жителей НП в период времени 5-20 лет после чернобыльских выпадений хорошо описывается процессами, учитывающими радиоактивный распад и естественную миграцию радионуклидов цезия с полупериодом уменьшения длинной компоненты 50 лет. 
exceed $12 \%$. This allows in the future use the model of external exposure [12] to estimate the doses to the population living on the territories contaminated after the Chernobyl accident.

\section{References (Литература)}

1. Erkin, V.G., Lebedev, O.V. Thermoluminescent dosimeter measurements of external doses to the population of the Bryansk region after the Chernobyl accident. In: Balonov M.I. and Merwin S.E., eds. The Chernobyl Papers. Vol. 1. Research Enterprises; Publishing Segment. Richland; Washington: 1993: p. 289-311.

2. Golikov, V.Yu.; Balonov, M.I.; Ponomarev, A.V. Estimation of external gamma-radiation doses to the population after the Chernobyl accident. In: Balonov M.I. and Merwin S.E., eds. The Chernobyl Papers. Vol.1. Research Enterprises; Publishing Segment; Richland; Washington; 1993: $p$ 247-288.

3. Skryabin, A.M.; Masyakin, V.B.; Osypenko, A.N.; Vlasova, N.C.; Savkin, M.N.; Grinev, M.; Lebedev, A.; Androsova, A.; Konstantinov, Y.O.; Erkin, V.G.; Korelina, N.F.; Moskalev, O.S.; Robinson, C.A.; Prosser, S.L.; Jones, K.A.; Morrey, $M$. Distribution of doses received in rural areas affected by the Chernobyl accident. NRPB-R277; Chilton; Didcot; Oxon OX11 ORQ; 1995

4. Jacob, P.; Prohl, G.; Likhtarev, I.; Kovgan, L.; Gluvchinsky, R.; Perevoznikov, O.; Balonov, M.I.; Golikov, V.; Ponomarev, A.; Erkin, V.; Vlasov, A.; Shutov, V.N.; Bruk, G.I.; Travnikova, I.G.; Kenigsberg,Y.E.; Buglova, E.E.; Shevchuk, V.E.; Morrey, M.; Prosser, S.L.; Jones, K.A.; Colgan, P.A.; Guardans, R.; Suacez, A.; Renaud, Ph.; Maubert, H.; Skryabin, A.M.; Vlasova, N.; Linge, I.; Epifanov, V.; Osipyants, I.; Skorobogotov, A. Pathway analysis and dose distributions. European Commission, Brussels: EUR $16541 \mathrm{EN}: 1$-130; 1996.

5. Likhtarev, I.; Kovgan, L.; Novak, D.; Vavilov, S.; Jacob, P.; Paretzke, H.G. (1996) Effective dose due to Chernobyl external irradiation for different population groups of Ukraine. Health Phys. 70: p. 87-98.

6. Golikov V.Yu., Balonov M.I., Jacob P. (2002) External Exposure of the Population Living in Areas of Russia Contaminated due to the Chernobyl Accident. Radiat. Environ. Biophysics, 41, Nr. 10, p. 185-193.

7. Golikov V., Balonov M., Erkin V., Jacob P. (1999) Model validation for external doses due to environmental contamination by the Chernobyl accident. Health Physics, v. 77, Nr. 6 , p. 654-661.

8. Golikov V., Wallström, E., Wöhni, T., Tanaka, K., Endo, S. and Hoshi, M. (2007) Evaluation of conversion coefficients from measurable to risk quantities for external exposure over contaminated soil by use of physical human phantoms. Radiation Environ. Biophysics, 46, Nr. 4, p. 375-382.
2. Распределение индивидуальных доз внешнего облучения жителей НП, нормированных на среднее значение дозы в НП, соответствует логарифмически нормальному закону с устойчивыми во времени параметрами (геометрическим средним значением и геометрическим стандартным отклонением), что позволяет, в частности, прогнозировать значение дозы в критической группе населения или для репрезентативного индивидуума (the representative person), согласно концепции МКР3 [12].

3. Сравнение значений средних эффективных доз внешнего облучения у жителей НП, оцененных на основании результатов двух различных методов измерений (измерений индивидуальных доз с использованием ТЛдозиметров и измерений мощностей доз в воздухе в различных локациях НП), показало их хорошую сходимость через 17 лет после аварии. В двух НП, где проводились измерения в 2003 г., относительные различия значений средних эффективных доз, полученных этими методами, не превышали 12\%. Это позволяет и в дальнейшем для оценки доз внешнего облучения населения, проживающего на территориях, подвергшихся радиоактивному загрязнению в результате Чернобыльской аварии, использовать методику, основанную на существующей модели внешнего облучения [13] совместно с результатами измерений мощностей доз в НП.

9. Roed, J., Lange, C., Andersson, K.G., Prip, H., Olsen, S. Ramzaev, V.P., Ponomarjov, A.V., Barkovsky, A.N., Mishin, A.S., Vorobiev, B.F., Chesnokov, A.V., Potapov, V.N., Shcherbak, S.B. Decontamination in a Russian settlement. Roskilde, Denmark: Rise National Laboratory; Risö-R-870 (EN); 1996

10. IRPA-10 $-10^{\text {th }}$ International Congress of the International Radiation Protection Association. Wallström, E., Thornberg, C., Vesanen, R., Zvonova, I., Jesko, T., Erkin, V., Wöhni, T., Cederblad, A., Mattsson, S., Alpsten, M., Golikov, V., Balonov, M. Assessments of effective dose to population groups in Sweden and Russia after the Chernobyl accident. P-11-258. In Proceedings of International Conference, May 14-19 2000, Hiroshima, Japan.

11. Methodological guidelines. MG 2.6.1.2003-05. Estimation of the mean annual effective doses of critical population group in settlements of Russian Federation affected by radioactive contamination due to Chernobyl NPP accident. Moscow, Rospotrebnadzor, 2005, 19 p. (In Russian). [Методические указания МУ 2.6.1.2003-05. Оценка средних годовых эффективных доз облучения критических групп жителей населенных пунктов Российской Федерации, подвергшихся радиоактивному загрязнению вследствие аварии на Чернобыльской АЭС. - М.: Роспотребнадзор, 2005. - 19 с.]

12. ICRP, 2008. Recommendation of the ICRP: ICRP Publication 103. Annals of the ICRP. 2008. V. 37, No. 2-4.

13. Methodological guidelines. MG 2.6.1.579-96. The reconstruction of population average accumulated in 1986 1995 effective exposure dose in radioactively contaminated Russian settlements after 1986 Chernobyl NPP accident. Moscow, Minzdrav of Russia, 1996, 33 p. (In Russian). [Методические указания МУ 2.6.1.579-96. Реконструкция средней накопленной в 1986-1995 гг. эффективной дозы облучения жителей населенных пунктов Российской Федерации, подвергшихся радиоактивному загрязнению вследствие аварии на Чернобыльской АЭС в 1986 году. М.: Минздрав России, 1996. - 33 с.]

Received: October 09, 2018 Поступила: 09.10.2018 г. 
Vladislav Yu. Golikov - Senior Researcher of the Medical Protection Laboratory, Saint-Petersburg Research Institute of Radiation Hygiene after Professor P.V. Ramzaev, Federal Service for Surveillance on Consumer Rights Protection and Human Well-Being. Address for correspondence: Mira Str., 8, Saint-Petersburg, 197101, Russia. E-mail: sg235@rambler.ru

Голиков Владислав Юрьевич - старший научный сотрудник лаборатории радиацинной гигиены медицинских организаций Санкт-Петербургского научно-исследовательского института радиационной гигиены имени профессора П.В. Рамзаева Федеральной службы по надзору в сфере защиты прав потребителей и благополучия человека. Адрес для переписки: 197101, Россия, Санкт-Петербург, ул. Мира, д. 8; E-mail: sg235@rambler.ru

For citation (Для цитирования): Golikov V.Yu. Analysis of the long-term dynamics of external doses of the population after the Chernobyl accident. Radiatsionnaya Gygiena = Radiation Hygiene, 2018, Vol. 11, No. 4, pp. 3950. DOI: 10.21514/1998-426x-2018-11-4-39-50

\section{МОНОГРАФИЯ \\ Природные источники ионизирующего излучения: дозы облучения, радиационные риски, профилактические мероприятия под редакиией академика РАН Г.Г. Онищенко и профессора А.Ю. Поповой}

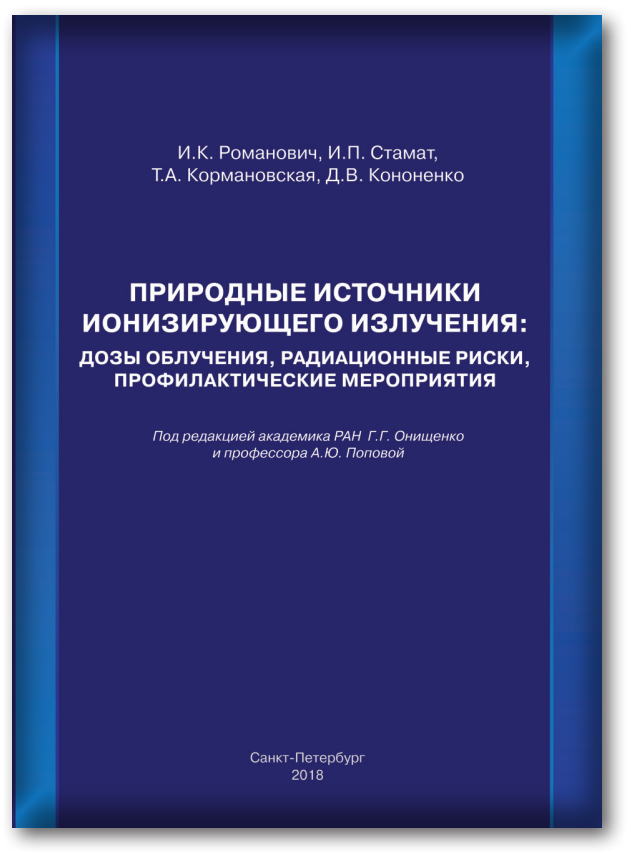

В 2018 г. под эгидой Санкт-Петербургского научно-исследовательского института радиационной гигиены им. профессора П.В. Рамзаева, Федеральной службы по надзору в сфере защиты прав потребителей и благополучия человека и Российской Академии наук, под редакцией академика РАН Г.Г. Онищенко и профессора А.Ю. Поповой опубликована монография «Природные источники ионизирующего излучения: дозы облучения, радиационные риски, профилактические мероприятия», посвященная памяти одного из авторов, - ведущего специалиста в области природного облучения, доктора биологических наук Ивана Павловича Стамата (1950-2017). В монографии, наряду с общими сведениями о природных источниках ионизирующего излучения, авторы И.К. Романович, И.П. Стамат, Т.А. Кормановская, Д.В. Кононенко и др. дают характеристику системы нормативно-правового регулирования в Российской Федерации, представля- ют данные о дозах природного облучения населения как в целом по стране, так и отдельно по каждому субъекту РФ. В монографии описаны подходы и оценены риски для населения при облучении природными источниками, предложены рекомендации по снижению доз облучения населения. Дозы облучения населения Российской Федерации от природных источников излучения значительно превышают дозы облучения от техногенных источников и от применения источников ионизирующего излучения и радиоактивных веществ в медицине, поэтому изучение путей облучения, мер профилактики и снижения доз природного облучения является кране важной задачей. Авторы надеются, что материалы, представленные в данной монографии, будут полезны специалистам, работающим в области радиационной гигиены и радиационной безопасности, и внесут свой вклад в снижение дозовой нагрузки на население Российской Федерации. 